\title{
PSEUDOMONAS AERUGINOSA INFECTION AND VACCINATION IN THE RAT
}

\author{
A. A. I. Kostiala \\ Department of Bacteriology and Immunology, University of Helsinki, \\ Haartmaninkatu 3, 00290 Helsinki 29, Finland
}

THE high levels of antibiotic resistance that occur in Pseudomonas aeruginosa have led to growing interest in the development of pseudomonas vaccines. After the introduction by Fisher, Devlin and Gnabasik (1969) of an immunotyping system for strains of $P$. aeruginosa, it was learned that a polyvalent antigen mixture was effective as a vaccine in burned patients, and that hyperimmune globulin from vaccinated donors had a beneficial effect in pseudomonas sepsis (Jones, Alexander and Fisher, 1973). Each of seven immunotype antigens was lipopolysaccharide (LPS) in nature (Hanessian et al., 1971). Vaccination produced IgG that was highly specific for the corresponding immunotype (Fisher, 1977).

A different approach to the development of a pseudomonas vaccine was used by Carney and Jones (1968) and Jones (1968). It was based on the use of large molecular fractions of culture filtrates of $P$. aeruginosa. In mice, they induced protection against a wide range of serotypes (Jones, 1972). Recently, a new polyvalent vaccine has been developed by extraction of the immunogens from pseudomonas cell walls (Miler et al., 1977); a ribosomal vaccine has also been described (Lieberman, 1978).

The purpose of the present study was to confirm and extend the work of Jones $(1968,1972)$ by investigating the immune response of rats to vaccines prepared from filtrates of $P$. aeruginosa cultures.

\section{MATERIALS AND METHODS}

Animals. Male and female rats of the locally produced inbred Sprague-Dawley strain were used. They were 8-12 weeks old and weighed $170-300 \mathrm{~g}$. In one experiment, inbred CBA mice were used at the age of 3-4 months.

Micro-organisms. The pseudomonas strains were typed at the Central Public Health Laboratory, London. P. aeruginosa strain ATCC9027 belonged to serotype 1 (Habs, 1957) and phage type 68,1214; a second strain from a human patient belonged to serotype Ps11 - a subgroup of Habs's serotype 2 - and phage type 44, 109, 1214. According to the new typing scheme of the Subcommittee on Pseudomonadaceae and Related Organisms of the International Committee of Systematic Bacteriology and the International Association of Microbiological Societies (see Bergan, 1975), these strains represent O-antigen groups 1 and 16, respectively. They were grown in Lab-Lemco Broth (Oxoid) and plated on blood agar.

The spleen of a mouse infected with Listeria monocytogenes strain EGD was cultured for $16 \mathrm{~h}$ in Trypticase Soy Broth (Baltimore Biological Laboratories). The culture was stored in liquid nitrogen until required.

Escherichia coli strain ATCC11775 was grown in broth and plated as above. 
Vaccines and vaccination. The vaccines were made by the method of Carney and Jones (1968). Synthetic liquid medium contained glucose $1.2 \%$, alanine $0.3 \%$, aspartic acid $0.3 \%$, glutamic acid $0.3 \%$, sodium chloride $0.3 \%$, potassium dihydrogen phosphate $0.15 \%$, calcium chloride $0.01 \%$, and magnesium sulphate $0.01 \%$. The $p \mathrm{H}$ was adjusted to 7.5 with Tris buffer and the medium was sterilised by Millipore filtration. P. aeruginosa was grown in 1 litre of synthetic medium for 5 days at $37^{\circ} \mathrm{C}$. The culture was centrifuged for $30 \mathrm{~min}$. at $2500 \mathrm{~g}$ and $4^{\circ} \mathrm{C}$. The supernate was sterilised by Millipore filtration and the filtrate concentrated by ultrafiltration through dialysis tubing to a volume of $2 \mathrm{ml}$, followed by dialysis for $24 \mathrm{~h}$ against tap water. The material was fractionated by gel filtration through a Sephadex G-200 column with phosphate-

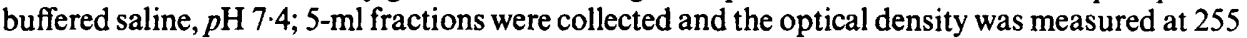
$\mu \mathrm{m}$ in a Hitachi Perkin-Elmer 124 spectrophotometer. The fractions corresponding to the first elution peak were pooled, dialysed against distilled water for $24 \mathrm{~h}$, filtered through a Millipore membrane, and lyophilised.

The rats and mice were vaccinated with pseudomonas vaccine prepared from serotype 1 ("vaccine 1") or serotype 16 ("vaccine 16") at doses of $1 \mu \mathrm{g}$ and $0.1 \mu \mathrm{g}$ per $\mathrm{g}$ of body weight, respectively. The vaccines were given intraperitoneally in volumes made up to $1 \mathrm{ml}$ by the addition of $0.9 \% \mathrm{NaCl}$ (saline). Unvaccinated control animals received $1 \mathrm{ml}$ of saline.

Infection of rats and mice. Broth suspensions of $P$. aeruginosa and $E$. coli were washed twice in saline and the organisms resuspended in saline at concentrations suitable for injection. The rats were infected by injecting $0 \cdot 1 \mathrm{ml}$ of bacterial suspension into the pad of each hind foot, and $0.3 \mathrm{ml}$ into the subcutis at the base of the tail. The mice received $0.05 \mathrm{ml}$ in each footpad and 0.2 $\mathrm{ml}$ at the base of the tail. In one experiment, rats were challenged intravenously with approximately $3 \times 10^{6} L$. monocytogenes in $1 \mathrm{ml}$ of saline.

LD50 determinations. Groups of five animals (rats or mice) were infected subcutaneously with doubling doses of $P$. aeruginosa or $E$. coli. They were observed daily for 14 days, after which period no more deaths occurred. The LD50 values were calculated by the method of Reed and Muench (1938).

Agglutination tests. Heat-stable $\mathrm{O}$ and heat-labile $\mathrm{H}$ antigens were prepared as described by Verder and Evans (1961). To ensure maximal motility for the $\mathrm{H}$-antigen preparations, $P$. aeruginosa was grown overnight at $20^{\circ} \mathrm{C}$ at the bottom of tubes containing semisolid agar (SIM Medium; Difco), and only the surface growth was used for seeding broth cultures. The antigen preparations were adjusted to a constant bacterial density in saline by means of a Carl Zeiss spectrophotometer (0.65 at $650 \mu \mathrm{m})$.

Serial twofold dilutions of sera were made in saline beginning at 1 in 5. Equal volumes of antigen preparation in saline were then added. Tests for $\mathrm{H}$ antibody were incubated in a waterbath at $50^{\circ} \mathrm{C}$ for $2 \mathrm{~h}$, and those for $\mathrm{O}$ antibody were incubated for $20 \mathrm{~h}$.

Immunodiffusion technique. Ouchterlony immunodiffusion tests were performed on glass slides covered with agarose gel $0.8 \%$ in veronal buffer at $p \mathrm{H} 7.6$; wells, $5 \mathrm{~mm}$ apart and $4 \mathrm{~mm}$ in diameter, were cut in the agar. Undiluted rat serum was placed in the central well; lyophilised pseudomonas vaccine of serotype 1 or 16 was placed in the peripheral wells in solutions containing $1,0.1$ and $0.01 \mathrm{mg} / \mathrm{ml}$ of saline. The slides were kept in a moist chamber for 1 day at room temperature and 3 days at $4^{\circ} \mathrm{C}$, and the appearance of precipitation bands was recorded.

Footpad swelling. The thickness of the right hind footpad of rats was measured with a caliper (Oditest; H.C. Kröplin, Schleuchtern, Germany) before infection with 1.2-1.7 $\times 10^{9}$ living $P$. aeruginosa (each hind footpad 2.5-3.4 $\times 10^{8}$ organisms in $0.1 \mathrm{ml}$ ) and at $1,2,3,4,6$ and 21 days thereafter. Increase in footpad thickness was used as an index of local inflammation.

Delayed-type hypersensitivity (DTH). The radiometric ear-index test and the ear-swelling measurement (Kostiala, 1977) were used. The following three types of antigen prepared from $P$. aeruginosa types 1 and 16 were used to test rats at intervals after infection. (1) Vaccines 1 and 16 (see above); each dose consisted of $1 \mu \mathrm{g}$ in $0.02 \mathrm{ml}$ saline. (2) Heat-killed antigen $\left(80^{\circ} \mathrm{C}, 1 \mathrm{~h}\right.$ ); each dose consisted of $1 \times 10^{8}$ cells in $0.02 \mathrm{ml}$ of saline. (3) Formalin-killed antigen, prepared as for $\mathrm{H}$ agglutinating antigen and washed twice in saline; each dose consisted of $1 \times 10^{7}$ cells in $0.02 \mathrm{ml}$ of saline.

Statistics. Comparisons between groups were made by Student's $t$-test. 


\section{RESULTS}

\section{Pseudomonas infection in rats}

The two serotypes of $P$. aeruginosa, 1 and 16, had different pathogenic effects in SD rats challenged subcutaneously. This difference was first seen when the LD50 values were determined.

LD50 determination. The rats either died during the first 3 days of infection, or survived. Serotype 16 proved to be a more virulent strain (LD50 $\left.4.3 \times 10^{8}\right)$ than type $1\left(\right.$ LD50 $\left.3.4 \times 10^{10}\right)$.

Agglutinin responses to pseudomonas antigens. The agglutinin titres of groups of rats immunised with $5 \times 10^{7}$ type- 1 or $2 \times 10^{7}$ type- 16 bacteria were measured. Measurable $\mathrm{O}$ - and $\mathrm{H}$-antibody responses (fig. 1) were first seen on the 3rd day after infection. Thereafter, rats infected with the more virulent type 16 developed high titres that persisted for at least 28 days. Although the dose of type-1 organisms was more than twice that of type-16 organisms, it produced lower titres; these titres reached a maximum on day 5 and rapidly declined thereafter. Neither of the two groups of rats showed $\mathrm{O}$ or $\mathrm{H}$ antibodies to the heterologous strain.

When the doses were increased to levels approaching the LD50 (table I), $\mathrm{O}$-agglutinin responses remained specific, but rats infected with type 1 produced $\mathrm{H}$ agglutinins against type 16 .

Delayed-type hypersensitivity. Subcutaneous infection in the hind quarters stimulates lymph nodes beneath the diaphragm and often leads to the development of DTH (Kostiala and McGregor, 1975). In the present experiments three different antigens were used to test rats 3-30 days after subcutaneous

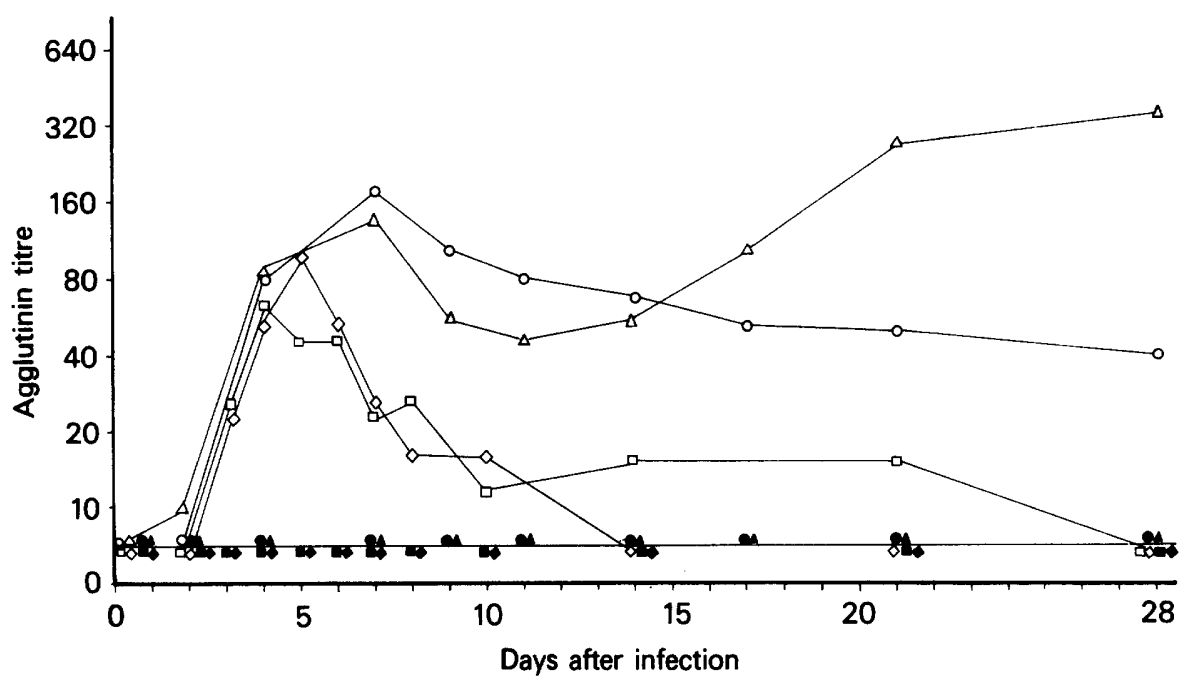

FIg. 1.-Agglutinin responses to the homologous Pseudomonas aeruginosa strain (open symbols). The anti-O $(0-0)$ and anti- $\mathrm{H}(\Delta-\Delta)$ titres in rats infected with $2 \times 10^{7}$ type-16 organisms were higher and more persistent than the anti-O $(\square-D)$ and anti- $\mathrm{H}_{(}\left({ }_{-}-\right)$) titres of rats infected with $5 \times 10^{7}$ type-1 organisms. The corresponding closed symbols show consistently negative heterologous responses. Means from 4-10 rats. 
TABLE I

Agglutinin response of rats infected with sublethal doses of Pseudomonas aeruginosa

\begin{tabular}{|c|c|c|c|c|c|}
\hline \multirow{3}{*}{$\begin{array}{c}\text { Rats infected } \\
\text { with } \\
\text { serotype }\end{array}$} & \multirow{3}{*}{$\begin{array}{c}\text { Dose of } \\
\text { organisms } \\
\left(10^{6}\right)\end{array}$} & \multicolumn{4}{|c|}{ Titre, ${ }^{*} 14$ days after infection, of } \\
\hline & & \multicolumn{2}{|c|}{ type 1} & \multicolumn{2}{|c|}{ type 16} \\
\hline & & $\mathrm{O}$ agglutinins & $\mathrm{H}$ agglutinins & $\mathrm{O}$ agglutinins & $\mathrm{H}$ agglutinins \\
\hline 1 & $\begin{array}{r}22000 \\
5500 \\
2300\end{array}$ & $\begin{array}{l}265 \pm 6 \\
208 \pm 6 \\
182 \pm 6\end{array}$ & $\begin{array}{l}158 \pm 7 \\
208 \pm 6 \\
120 \pm 7\end{array}$ & $\begin{array}{l}<10 \\
<10 \\
<10\end{array}$ & $\begin{array}{l}320 \pm 0 \\
548 \pm 6 \\
239 \pm 6\end{array}$ \\
\hline 16 & $\begin{array}{l}460 \\
290\end{array}$ & $\begin{array}{l}<10 \\
<10\end{array}$ & $\begin{array}{l}<10 \\
<10\end{array}$ & $\begin{array}{l}320 \pm 0 \\
320 \pm 0\end{array}$ & $\begin{array}{r}2560 \pm 0 \\
629 \pm 10\end{array}$ \\
\hline
\end{tabular}

* Means from 3 or 4 animals, $\pm \mathrm{SE}$.

infection with a low $\left(2-5 \times 10^{7}\right)$ or a high $\left(1 \times 10^{8}-2 \times 10^{10}\right)$ number of organisms. The results were negative.

\section{Vaccination of mice}

In an experiment of which the results are shown in table II, a single intraperitoneal injection $(0.1 \mu \mathrm{g}$ per $\mathrm{g}$ body weight) of vaccine, prepared by the method of Carney and Jones (1968) from either type 1 or 16 of $P$. aeruginosa, protected groups of mice against subcutaneous infection with both the homologous and heterologous organisms.

This supported the findings of Jones (1968 and 1972).

TABLE II

Cross protection of mice by $P$. aeruginosa vaccines

\begin{tabular}{l|cc}
\hline $\begin{array}{c}\text { Mice pretreated } \\
\text { intraperitoneally } \\
\text { with }\end{array}$ & $\begin{array}{c}\text { LD50 values* obtained by challenging } \\
\text { (subcutaneously, 4 days after vaccination) with }\end{array}$ \\
\cline { 2 - 2 } & type-1 organisms & type-16 organisms \\
\hline vaccine $1(0.1 \mu \mathrm{g} / \mathrm{g}$ body weight) & $2.8 \times 10^{9}$ & $2.2 \times 10^{8}$ \\
vaccine $16(0.1 \mu \mathrm{g} / \mathrm{g}$ body weight) & $2.2 \times 10^{9}$ & $2.0 \times 10^{8}$ \\
saline & $5.0 \times 10^{8}$ & $5.5 \times 10^{7}$ \\
\hline
\end{tabular}

* Determined 14 days after challenge.

\section{Effects of $P$. aeruginosa vaccines in rats}

Serotype 1 was found to be avirulent for rats (LD50 $3.4 \times 10^{10}$ ); it was therefore unsuitable for use as a challenge strain in experiments on pseudomonas vaccines.

Protection and local reaction. Five groups of rats were vaccinated intraperitoneally (vaccine $1 ; 1 \mu \mathrm{g} / \mathrm{g}$ body weight) on different occasions within a period of 14 days; a control group was given saline alone. Two weeks after 


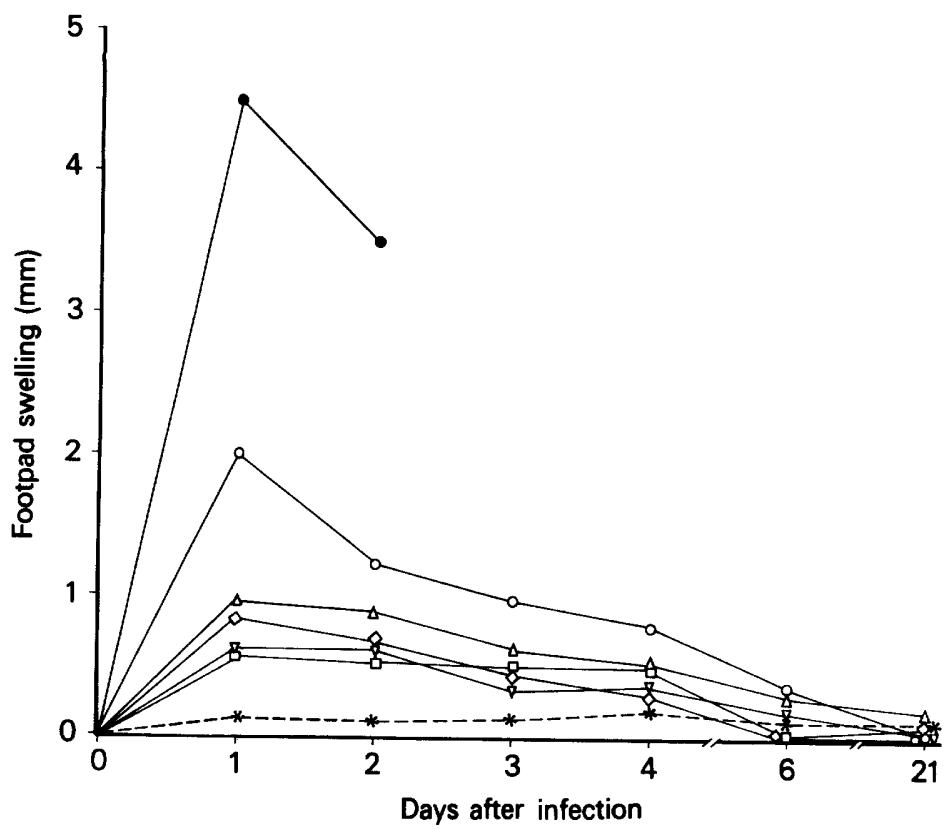

FIG. 2.- Swelling of the right hind footpad of rats infected with $1.7 \times 10^{9} P$. aeruginosa, serotype 16 (each hind footpad $0.1 \mathrm{ml}$, base of tail $0.3 \mathrm{ml}$ ). Unvaccinated control rats $=\bullet$ Rats vaccinated intraperitoneally $(1 \mu \mathrm{g} / \mathrm{g}$ body weight) with type-16 vaccine 3 days before infection $=\diamond-\diamond ; 5$ days before $=0-\square ; 7$ days before $=\nabla-\nabla ; 9$ days before $=\Delta-\Delta ; 14$ days before $=0-0 . * *---*=-$ Footpad swelling in normal rats inoculated with $0.1 \mathrm{ml}$ of saline. Means from 3-5 rats.

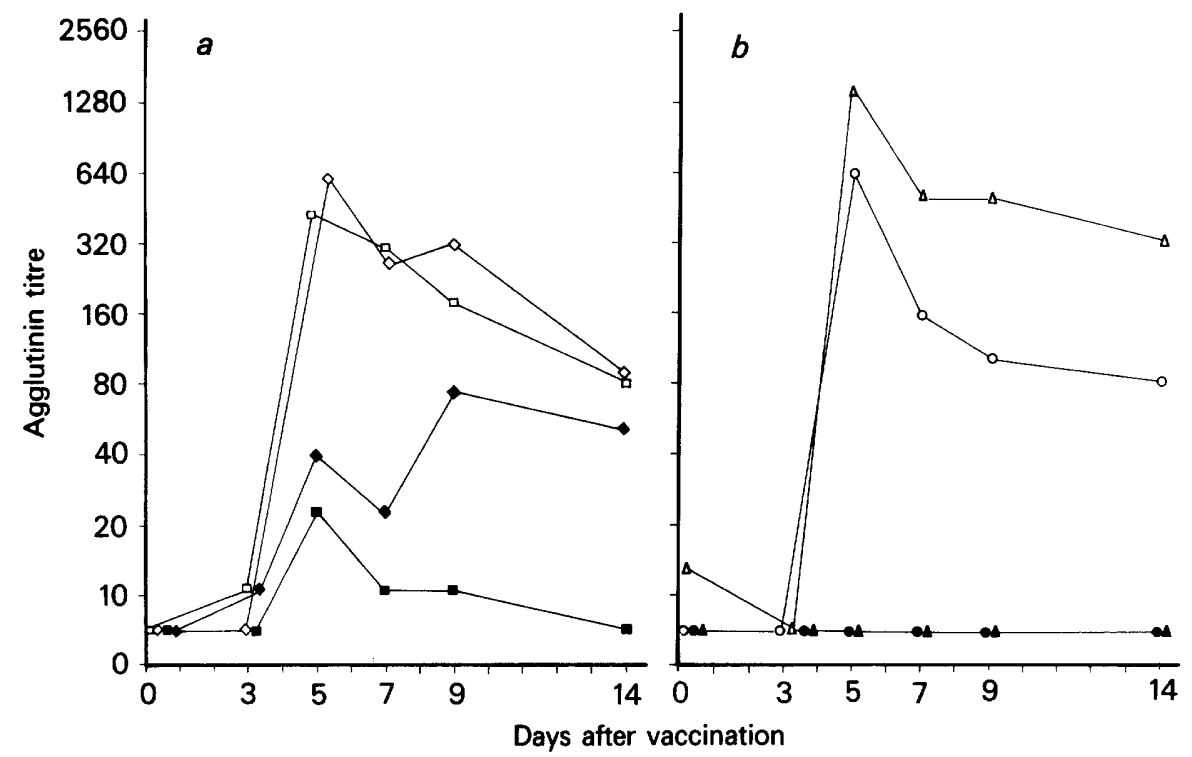

FIG. 3.-Agglutinin response to the homologous (open symbols) and heterologous (closed symbols) serotypes of $P$. aeruginosa in rats inoculated intraperitoneally with type- 1 or type-16 vaccine $(1 \mu \mathrm{g} / \mathrm{g}$ body weight). Anti-O ( $\square-\square)$ and anti-H $(\diamond-\diamond)$ homologous agglutinins in rats that received vaccine 1 are shown (a), together with anti-O (-) and anti-H $(\bullet)$ heterologous agglutinins. In rats given vaccine 16 (b) homologous agglutinins only were detected (o- $0=$ anti-O; $\Delta-\Delta=$ anti-H). Means from four rats. 
vaccination of the first group and 3 days after vaccination of the last group, all the rats were bled from the tail for serum antibody determinations and blood leucocyte counts. They were then challenged subcutaneously in the hind footpads and at the base of the tail with a total of $1.2 \times 10^{9}$ type-16 organisms. Five similar groups of rats received vaccine $16(1 \mu \mathrm{g} / \mathrm{g}$ body weight $)$ and, together with a control group, were challenged with $1.7 \times 10^{9}$ type-16 organisms.

By $72 \mathrm{~h}$, all the control rats had died, whereas all those given either vaccine $3,5,7,9$ and 14 days earlier were still alive 4 weeks later. The survival data corresponded well with footpad inflammation. Fig. 2 shows the results in rats given vaccine 16 . In unprotected control rats infected with $1.7 \times 10^{9}$ type-16 organisms, of which $3.4 \times 10^{8}$ were injected into the footpad, haemorrhagic swollen lesions rapidly developed in the footpads within 1 day of infection. In groups treated with vaccine 16 the swelling was significant $(\mathrm{p}<0.01)$ but only moderate in size, being greatest in the group vaccinated 14 days earlier. The results were similar in rats that received vaccine 1 .

Agglutinins and precipitins. The results are illustrated in fig. 3. Antibody could not be detected 3 days after vaccination; the titres then rose rapidly to a maximum on day 5. Vaccine 16 produced no $\mathrm{O}$ and $\mathrm{H}$ agglutinins against type-1 organisms; vaccine 1 produced low titres of $\mathrm{O}$ and $\mathrm{H}$ agglutinin against type-16 organisms from the 5th day onwards. Ouchterlony's immunodiffusion method (table III) revealed antibody that formed a precipitate with homologous vaccine containing $1 \mathrm{mg}$ of lyophilised antigen $/ \mathrm{ml}$; this antibody was present from the 5th day onwards.

The protective effect of sera from vaccinated rats. Groups of four rats were dosed intravenously ( $2 \mathrm{ml}$ per rat) with pooled sera from donor rats treated 3 days earlier with vaccine 1 or 16 , or from donor rats treated 14 days earlier with vaccine 1. A control group received pooled sera from normal rats. One hour later all rats were inoculated subcutaneously with $1.6 \times 10^{9}$ type-16 organisms. Within 3 days all died except two of four rats treated with serum taken from animals vaccinated 14 days earlier. The failure of passive protection tests to demonstrate serum antibody in rats immunised by vaccination 3 days earlier may have been due to the limitations of the method-antibody titres in recipients are inevitably less than those in donors. However, it seemed

TABLE III

Immunodiffusion reactions of sera from rats given $P$. aeruginosa vaccines

\begin{tabular}{l|lllll}
\hline \multirow{2}{*}{$\begin{array}{c}\text { Rats vaccinated } \\
\text { intraperitoneally } \\
\text { with }\end{array}$} & \multicolumn{4}{c}{$\begin{array}{c}\text { Number of sera (of groups of four) positive* at } \\
\text { the stated intervals (days) after vaccination }\end{array}$} \\
\cline { 2 - 6 } & 3 & 5 & 7 & 9 & 14 \\
\hline vaccine $1(1 \mu \mathrm{g} / \mathrm{g}$ body weight) & 0 & 2 & 3 & 3 & 3 \\
vaccine $16(1 \mu \mathrm{g} / \mathrm{g}$ body weight) & 0 & 3 & 4 & 4 & 2 \\
\hline
\end{tabular}

* Control rats that received only saline remained negative. Each serum was tested against homologous vaccine $(1 \mathrm{mg} / \mathrm{ml})$. 


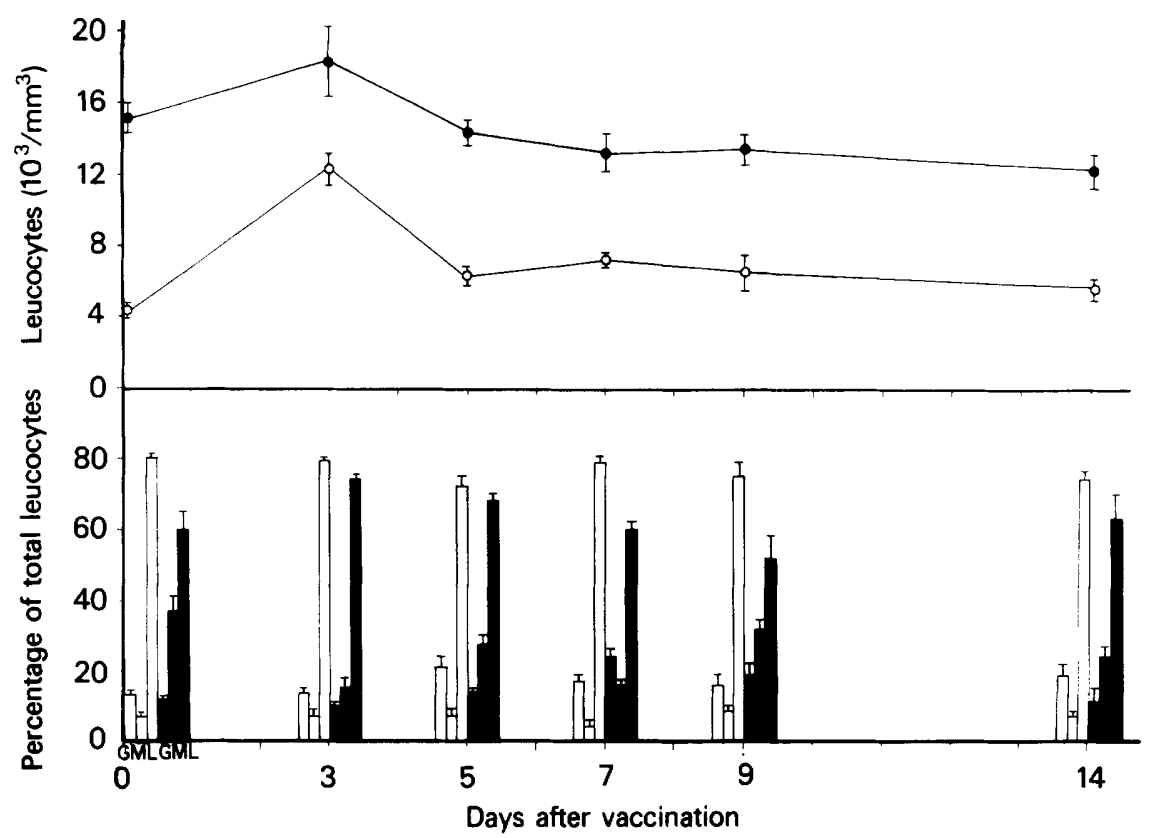

FIG. 4.-Leucocyte counts in rats at intervals after intraperitoneal vaccination with $P$. aeruginosa vaccine (1 $\mu \mathrm{g} / \mathrm{g}$ body weight $) 1(\circ-0)$ or $16(\bullet-\bullet)$. Bar graph gives the percentages of polymorphonuclear granulocytes $(G)$, monocytes $(M)$ and lymphocytes $(\mathrm{L})$ of total leucocytes. Means \pm SE from four rats.

possible that cell-mediated or other mechanisms might be concerned, and the following experiments were therefore made.

Blood leucocyte response. Fig. 4 shows that the highest levels of cell counts occurred 3 days after intraperitoneal vaccination. However, all the total counts as well as the percentages of polymorphonuclear granulocytes, monocytes and lymphocytes were within the normal limits for rats (Altman and Dittman, 1961).

Macrophage activation. L. monocytogenes is an intracellular organism readily disposed of by activated macrophages (Kostiala and McGregor, 1975; McGregor and Kostiala, 1976). It was used (table IV) to challenge rats

TABLE IV

Growth of Listeria monocytogenes in the tissues of rats given P. aeruginosa vaccines

\begin{tabular}{|c|c|c|c|c|}
\hline \multirow{3}{*}{$\begin{array}{l}\text { Rats pretreated } \\
\text { intraperitoneally with }\end{array}$} & \multicolumn{4}{|c|}{$\log _{10}$ viable listeria in } \\
\hline & \multicolumn{2}{|c|}{$\begin{array}{l}\text { liver, at the stated } \\
\text { intervals (hours) after } \\
\text { intravenous challenge* }\end{array}$} & \multicolumn{2}{|c|}{$\begin{array}{l}\text { spleen, at the stated } \\
\text { intervals (hours) after } \\
\text { intravenous challenge* }\end{array}$} \\
\hline & 1 & 24 & 1 & 24 \\
\hline $\begin{array}{l}\text { vaccine } 1(1 \mu \mathrm{g} / \mathrm{g} \text { body weight }) \\
\text { vaccine } 16(1 \mu \mathrm{g} / \mathrm{g} \text { body weight }) \\
\text { saline }\end{array}$ & $\begin{array}{l}6.07 \pm 0.11 \\
6.01 \pm 0.11 \\
6 \cdot 18 \pm 0.05\end{array}$ & $\begin{array}{l}7.06 \pm 0.05 \\
7.05 \pm 0.09 \\
7.49 \pm 0.04\end{array}$ & $\begin{array}{l}4.89 \pm 0.03 \\
4.86 \pm 0.05 \\
4.85 \pm 0.06\end{array}$ & $\begin{array}{l}7.09 \pm 0.05 \\
6.95 \pm 0 \cdot 15 \\
7.26 \pm 0.03\end{array}$ \\
\hline
\end{tabular}

* Three days after vaccination the rats were challenged with $5 \times 10^{6}$ listeria. 
TABLE V

Protection against Escherichia coli with P. aeruginosa vaccines

\begin{tabular}{|c|c|c|c|c|}
\hline \multirow{2}{*}{$\begin{array}{l}\text { Rats pretreated } \\
\text { intraperitoneally with }\end{array}$} & \multicolumn{4}{|c|}{$\begin{array}{l}\text { Number of dead rats (of groups of five) at } \\
\text { the stated intervals (days) after subcutaneous } \\
\text { challenge* with } 2 \times 10^{10} \mathrm{E} \text {. coli }\end{array}$} \\
\hline & 1 & 2 & 3 & 4 \\
\hline $\begin{array}{l}\text { vaccine } 1(1 \mu \mathrm{g} / \mathrm{g} \text { body weight }) \\
\text { vaccine } 16(1 \mu \mathrm{g} / \mathrm{g} \text { body weight }) \\
\text { saline }\end{array}$ & $\begin{array}{l}0 \\
0 \\
3\end{array}$ & $\begin{array}{l}0 \\
2 \\
5\end{array}$ & $\begin{array}{l}1 \\
3 \\
5\end{array}$ & $\begin{array}{l}2 \\
4 \\
5\end{array}$ \\
\hline
\end{tabular}

* Rats were challenged 3 days after vaccination.

(intravenously, $5 \times 10^{6}$ organisms per animal) vaccinated 3 days earlier with pseudomonas vaccine. The viable bacterial counts in the liver and spleen were compared with those of unvaccinated rats. No differences occurred $1 \mathrm{~h}$ after challenge, but at $24 \mathrm{~h}$ the numbers of organisms in vaccinated rats were slightly less than those in the controls (liver, $\mathrm{p}<0.01$; spleen, $\mathrm{p}<0.05$ ).

Protection against $E$. coli. The LD50 for rats by subcutaneous injection was $8.5 \times 10^{9}$, deaths occurring within 4 days. Groups of five rats were given vaccine 1 , vaccine 16 , or saline. Three days later they were all infected with $2.0 \times 10^{10} \mathrm{E}$. coli. Vaccination clearly retarded death (table V). Of 10 vaccinated rats, four survived; all the controls died within 2 days of challenge. It was observed in other experiments that unprotected rats that had been challenged with a high but sublethal dose of $E$. coli became severely ill, whereas vaccinated rats did not.

\section{Discussion}

Typing procedures for $P$. aeruginosa include bacteriophage and pyocine typing, and antibiograms, in addition to serological typing schemes, the most widely used of which are those of Habs (1957), Verder and Evans (1961), and Fisher et al. (1969). In the scheme of Verder and Evans (1961) 10 thermolabile $\mathrm{H}$ antigens were used to supplement $\mathrm{O}$ grouping. Investigators have since found it difficult to make specific flagellar antisera, presumably because the heat-labile components of $P$. aeruginosa may include surface antigens other than the single polar flagellum (Brokopp, Gomez-Lus and Farmer, 1977). Recently, the International Subcommittee on Pseudomonadaceae and Related Organisms (see Bergan, 1975) proposed a set of standard antigenic strains for preparing typing sera. According to this scheme, there are $17 \mathrm{O}$-antigenic groups of $P$. aeruginosa (Brokopp et al., 1977).

In the present experiments, $\mathrm{H}$ antigens were prepared from two $\mathrm{O}$-antigen types by the method of Verder and Evans (1961). In infected rats, agglutinins to the homologous strain only were found (fig. 1), except when a very large dose of type-1 organisms was used (table I). Vaccines prepared from type-1 organisms induced moderate $\mathrm{H}$-agglutinin titres and low $\mathrm{O}$-agglutinin titres against type 16 but not vice versa (fig. 3). Young, Yu and Armstrong (1970) 
and Sadoff and Artenstein (1974) found that sera from subjects convalescing from $P$. aeruginosa infections sometimes had antibodies to multiple LPS antigens, although the infecting organisms reacted with only one type specific antiserum.

Evidence of DTH in pseudomonas-infected rats could not be found although highly sensitive assays (Kostiala, 1977) were used. This accords with the observations of Hoiby, Andersen and Bendixen (1975) in man but contrasts with those of Munster and Leary (1977). DTH is associated with cell-mediated resistance against many intracellular organisms (McGregor and Kostiala, 1976); pseudomonas infection is not intracellular, and DTH may not be concerned in resistance to it.

Pseudomonas LPS is less toxic than LPS from other gram-negative bacteria (Michaels and Eagon, 1966). It cannot be regarded as the primary factor in the pathogenesis of $P$. aeruginosa infection (Liu, Abe and Bates, 1961). $P$. aeruginosa produces virulence factors that include exotoxin (Liu et al., 1961; Snell et al., 1978), proteases (Liu et al., 1961; Morihara, 1963; Liu, 1966; Snell et al., 1978), hemolysins (Liu et al., 1961; Vymola and Lochmann, 1974) and slime (Liu et al., 1961; Sensakovic and Bartell, 1974). Exotoxin A, which like diphtheria toxin inhibits protein synthesis (Igewski, Liu and Kabat, 1977), is produced in vitro by most $P$. aeruginosa strains (Pollack, Taylor and Callahan, 1977); it is produced within lesions (Saelinger, Snell and Holder, 1977), is cytotoxic for macrophages, and induces liver necrosis (Pavlovskis, Voelker and Schackelford, 1976; Pollack and Anderson, 1978). Although antitoxin neutralises cytotoxity in vitro (Leppla, 1976), the manifestations of pseudomonas infection cannot all be ascribed to toxin, and antitoxin does not protect from a lethal challenge (Snell et al., 1978; Stieritz and Holder, 1978). High antibody levels to exotoxin $\mathrm{A}$ and proteases in cystic fibrosis patients were directly related to the severity of the disease (Klinger et al., 1978). Pseudomonas slime consists of high molecular-weight polysaccharides (Evans and Linker, 1973) and is more toxic than LPS; it produces leucopenia and death. These could be prevented by active or passive immunisation against the slime, but the protection was type specific (Sensakovic and Bartell, 1974).

The vaccine used in the present experiments was a large molecular-weight fraction of pseudomonas culture filtrate, and presumably contained several components. It should be noted that their use led to cross-protection against other O-antigen types that also belonged to different Fisher immunotypes (Young and Moody, 1974), and even to protection against unrelated organisms such as $E$. coli. This may have been due in part to macrophage activation; vaccinated rats possessed some increased resistance against $L$. monocytogenes. However, common antigens have been demonstrated in $P$. aeruginosa, E. coli and L. monocytogenes (Hoiby, 1975). It is known that the "backbone" of the core polysaccharide of pseudomonas LPS is similar to that of enterobacterial LPS (Chester, Gray and Wilkinson, 1972); antibody against it may protect against many gram-negative bacteria (McCabe et al., 1977). Braude et al. (1977) showed that vaccination with the core glycolipid of $E$. coli protected rabbits against pseudomonas bacteriaemia; the present results 
demonstrate the effect of pseudomonas vaccines against $E$. coli. The mechanisms of this protection is not known, but opsonic and antitoxic activity may be concerned (Braude et al., 1977).

Vaccines should be developed by isolating and characterising the surface antigens of $P$. aeruginosa. Success in man and in experimental animals has been reported with such preparations (Miler et al., 1977; Jones, Roe and Gupta, 1978).

\section{SUMMARY}

A large molecular-weight fraction of Pseudomonas aeruginosa culture filtrate protected rats and mice against a lethal infection with a heterologous serotype, and to some extent against Escherichia coli and Listeria monocytogenes. The active components were obtained from cultures grown for several days in a simple synthetic medium. Infection and vaccination with $P$. aeruginosa serotype 16 induced agglutinating and precipitating antibodies to the components of this serotype only; in rats infected or vaccinated with serotype 1 , low titres of agglutinating antibody against type 16 were found. Vaccine prepared from type 1 or 16 increased, within 3 days of infection, the resistance of rats to type- 16 organisms; within the same period agglutinins or precipitins were not produced. It is possible that the protection was based on opsonic and antitoxic activities.

Dr T. L. Pitt, Central Public Health Laboratory, London, kindly typed the P. aeruginosa strains used. The assistance of Mrs Leila Fabritius and Mrs Maire Laakso is gratefully acknowledged. This work was supported by a grant from the Sigrid Juselius Foundation, Helsinki to Dr T. U. Kosunen, and by a grant from the Emil Aaltonen Foundation, Tampere, Finland.

\section{REFERENCES}

Altman, P. L. AND Ditrman, D. S. 1961. Blood and other body fluids. Biological handbook. Federation of American Societies for Experimental Biology: Washington, D.C., p. 127.

Bergan, T. 1975. In Epidemiological typing of Pseudomonas aeruginosa, edited by M. W. R. Brown. Wiley: London, p. 189.

Braude, A. I., Ziegler, E. J., Douglas, H. and McCutchan, J. A. 1977. Antibody to cell wall glycolipid of gram-negative bacteria: induction of immunity to bacteremia and to endotoxemia. J. infect. Dis., 136, suppl., S167.

BRokopP, C. D., Gomez-Lus, R. AND FARMeR, J. J. 1977. Serological typing of Pseudomonas aeruginosa: use of commercial antisera and live antigens. J. clin. Microbiol., 5, 640.

CARneY, S. A. AND Jones, R. J. 1968. Biological and immunochemical properties of culture filtrates of virulent and avirulent strains of Pseudomonas aeruginosa. Br. J. exp. Path., 49, 395.

Chester, I. R., Gray, G. W. AND Wilkinson, S. G. 1972. Further studies of the chemical composition of the lipopolysaccharide of Pseudomonas aeruginosa. Biochem. J., 126, 395.

Evans, L. R. AND LinKer, A. 1973. Production and characterization of the slime polysaccharide of Pseudomonas aeruginosa. J. Bact., 116,915.

Fisher, M. W. 1977. A polyvalent human $\gamma$-globulin immune to Pseudomonas aeruginosa: passive protection of mice against lethal infection. J. infect. Dis., suppl., 136, S181. 
Fisher, M. W., Devlin, H. B., and Gnabasik, F. J. 1969. New immunotype schema for Pseudomonas aeruginosa based on protective antigens. J. Bact., 98, 835.

HaBS, I. 1957. Untersuchungen über die O-antigene von Pseudomonas aeruginosa. Z. Hyg. InfektKrankh., 144, 218.

Hanessian, S., Regan, W., Watson, D. AND Haskell, T. H. 1971. Isolation and characterization of antigenic components of a new heptavalent Pseudomonas vaccine. Nature (New Biol.), 229, 209.

HoIBY, N. 1975. Cross-reactions between Pseudomonas aeruginosa and thirty-six other bacterial species. Scand. J. Immun., 4, suppl., 2, 187.

Hoiby, N. Andersen, V. AND Bendixen, G. 1975. Pseudomonas aeruginosa infection in cystic fibrosis. Humoral and cellular immune responses against Pseudomonas aeruginosa. Acta path. microbiol. scand., (C), 83, 459.

IgLeWsKi, B. H., LiU, P. V. AND KABAT, D. 1977. Mechanism of action of Pseudomonas aeruginosa exotoxin A: adenosine diphosphate-ribosylation of mammalian elongation factor 2 in vitro and in vivo. Infect. Immun., 15, 138.

JONES, R. J. 1968. Protection against Pseudomonas aeruginosa infection by immunisation with fractions of culture filtrates of Ps. aeruginosa. Br. J. exp. Path., 49, 411.

JONES, R. J. 1972. Specificity of early protective responses induced by pseudomonas vaccines. $J$. Hyg., Camb., 70, 343.

Jones, C. E., AleXander, J. W. ANd Fisher, M. 1973. Clinical evaluation of Pseudomonas hyperimmune globulin. J. surg. Res., 14, 87.

Jones, R. J., RoE, E. A. AND GUPTA, J. L. 1978. Low mortality in burned patients in a Pseudomonas vaccine trial. Lancet, 2, 401.

Klinger, J. D., Straus, D. C., Hilton, C. B. and Bass, J. A. 1978. Antibodies to proteases and exotoxin A of Pseudomonas aeruginosa in patients with cystic fibrosis: demonstration by radioimmunoassay. J. infect. Dis., 138, 49 .

Kostiala, A. A. I. 1977. Radiometric ear index test as a measure of delayed-type hypersensitivity in the rat. Immunology, 33, 561 .

Kostiala, A. A. I. AND MCGrEGOR, D. D. 1975. The mediator of cellular immunity. IX. The relationship between cellular hypersensitivity and acquired cellular resistance in rats infected with Listeria monocytogenes. J. exp. Med., 141, 1249.

LEPPLA, S. H. 1976. Large-scale purification and characterization of the exotoxin of Pseudomonas aeruginosa. Infect. Immun., 14, 1077.

Lieberman, M. M. 1978. Pseudomonas ribosomal vaccines: preparation, properties and immunogenicity. Infect. Immun., 21, 76.

LiU, P. V. 1966. The roles of various fractions of Pseudomonas aeruginosa in its pathogenesis. II. Effects of lecithinase and protease. J. infect. Dis., 116, 112.

LiU, P. V., ABE, Y. AND BATES, J. L. 1961. The roles of various fractions of Pseudomonas aeruginosa in its pathogenesis. J. infect. Dis., 108, 218.

McCabe, W. R., Bruins, S. C., Craven, D. E. AND Johns, M. 1977. Cross-reactive antigens: their potential for immunization-induced immunity to gram-negative bacteria. J. infect. Dis., 136, suppl., S161.

MCGregor, D. D. AND Kostiala, A. A. I. 1976. The role of lymphocytes in cellular resistance to infection. Contemp. Top. Immunobiol., 5, 237.

Michaels, G. B. AND EAGON, R. G. 1966. The effect of ethylenediamine-tetra acetate and of lysozyme on isolated lipopolysaccharide from Pseudomonas aeruginosa. Proc. Soc. exp. Biol. Med., 122, 866.

Miler, J. M., Spilsbury, J. F., Jones, R. J., Roe, E. A. And Lowbury, E. J. L. 1977. A new polyvalent Pseudomonas vaccine. J. med. Microbiol., 10, 19.

MoRIHARA, K. 1963. Pseudomonas aeruginosa proteinase. I. Purification and general properties. Biochim. biophys. Acta, 73, 113.

Munster, A. M. And Leary, A. G. 1977. Cell-mediated immune responses to Pseudomonas aeruginosa. Am. J. Surg., 133, 710.

Pavlovskis, O. R., Voelker, F. A. ANd Shackelford, A. H. 1976. Pseudomonas aeruginosa exotoxin in mice: histopathology and serum enzyme changes. J. infect. Dis., 133, 253. 
Pollack, M. ANd ANDERSon, S. E. JR. 1978. Toxicity of Pseudomonas aeruginosa exotoxin A for human macrophages. Infect. Immun., 19, 1092.

Pollack, M., Taylor, N. S. and Callahan, L. T. 1977. Exotoxin production by clinical isolates of Pseudomonas aeruginosa. Infect. Immun., 15, 776.

REED, L. J. AND MUENCH, H. 1938. A simple method of estimating fifty per cent endpoints. Am. J. Hyg., 27, 493.

SAdoff, J. C. AND ARtenstein, M. S. 1974. The outer cell-wall membrane of Pseudomonas aeruginosa. J. infect. Dis., 130, suppl., S81.

SAELINGER, C. B., SNell, K. AND HoldER, I. A. 1977. Experimental studies on the pathogenesis of infections due to Pseudomonas aeruginosa: direct evidence for toxin production during pseudomonas infection of burned skin tissues. J. infect. Dis., 136, 555.

Sensakovic, J. W. AND Bartell, P. F. 1974. The slime of Pseudomonas aeruginosa: biological characterization and possible role in experimental infection. J. infect. Dis., 129, 101.

Snell, K., Holder, I. A., Leppla, S. A. and Saelinger, C. B. 1978. Role of exotoxin and protease as possible virulence factors in experimental infections with Pseudomonas aeruginosa. Infect. Immun., 19, 839.

STIERITZ, D. D. AND Holder, I. A. 1978. Experimental studies of the pathogenesis of Pseudomonas aeruginosa infection: evidence for the in-vivo production of a lethal toxin. J. med. Microbiol., 11, 101.

VERDER, E. AND EVANS, J. 1961. A proposed antigenic schema for the identification of strains of Pseudomonas aeruginosa. J. infect. Dis., 109, 183.

Vymola, F. ANd Lochmann, O. 1974. Characteristics of Pseudomonas haemolysin. J. Hyg. Epidem. Microbiol. Immun., 18, 302.

Young, L. S., YU, B. H. AND Armstrong, D. 1970. Agar-gel precipitating antibody in Pseudomonas aeruginosa infections. Infect. Immun., $2,495$.

Young, V. M. AND MoOdy, M. R. 1974. Serotyping of Pseudomonas aeruginosa. J. infect. Dis., suppl., 130, $\mathbf{S 4 7 .}$ 